\title{
Consumo de Substâncias / Drug Use
}

https://doi.org/10.21814/uminho.ed.36.10

\section{Cláudia Urbano}

CICS.NOVA - Centro Interdisciplinar de Ciências Sociais da Faculdade de Ciências Sociais e Humanas da Universidade NOVA de Lisboa, Portugal 



\section{Consumo de Substâncias}

As substâncias psicoativas, usualmente também referidas como drogas, são produtos que, quando consumidos, potenciam um efeito fisiológico e provocam alterações comportamentais. São diversas as classificações que podem ser usadas, sendo a mais comum a que diferencia as substâncias enquanto estimulantes, perturbadoras, narcóticos e alucinogénios. Diferenciam-se, também, quanto ao seu caráter legal (lícitas e ilícitas), dependendo, neste caso, do quadro normativo de cada sociedade. Segundo dados do último inquérito nacional ao consumo de substâncias psicoativas em Portugal, as de uso mais comum são a canábis, a cocaína e o ecstasy (Balsa et al., 2018). Nos estudos sobre os consumos de substâncias incluem-se também o álcool, o tabaco e os medicamentos sedativos ou estimulantes sem prescrição médica.

O consumo de substâncias é um dos comportamentos de risco identificados na sociedade em geral, e que afeta, em particular, o grupo dos jovens. É uma fase que pode revelar nos jovens uma certa insegurança face a novos estilos de vida: as responsabilidades passam gradualmente a ser outras, em direção a uma maior autonomia e emancipação; os contactos sociais, os papéis sociais e as rotinas mudam, diversificam e intensificam em alguns casos. Em torno dessas mudanças, há expectativas a gerir - suas e dos outros face às solicitações internas (dos desejos, aspirações e do desenvolvimento em geral dos jovens adultos) e externas (da sociedade e do mercado de trabalho). É também uma fase de afirmação pessoal e de necessidade de pertença a um grupo. A influência dos pares, o desejo de antecipar e replicar comportamentos da população adulta, a curiosidade e o desafio de experimentar, a tentação de testar o limite do normativo são algumas das razões que levam a uma primeira experiência de consumo de substâncias psicoativas e que podem potenciar o desenvolvimento de consumos mais regulares, mais intensos e mesmo mais problemáticos, chegando a situações de dependência e a consequências físicas, mentais e sociais graves.

Desta forma, os jovens tendem a adotar condutas pouco saudáveis, muitas delas associadas ao consumo de substâncias. Segundo os resultados europeus mais recentes de inquéritos nacionais à população jovem (EMCDDA, 2016), dois em cada dez jovens fumam regularmente, sete em cada dez 
consumiram álcool no último ano e dois a três deles com consumo binge (acima das quatro bebidas nas raparigas e das seis nos rapazes, numa mesma ocasião), e entre um a dois em cada dez já experimentaram qualquer tipo de droga (sendo a mais comum a canábis). Tanto na população geral como nos jovens, varia em função do género, sendo mais frequente entre a população masculina. No entanto, tem havido progressivamente nos últimos anos um aproximar das prevalências de consumo das raparigas face ao que são os padrões de consumo nos rapazes, sobretudo no que se refere ao consumo de tabaco, de álcool e de canábis.

Os contextos de consumo de substâncias mais frequentes são as festas associadas a rituais de passagem (fim de ano civil, final de ano escolar, fim de curso) e a eventos lúdico-culturais organizados (festas rave, transe, festivais de verão). É frequente o consumo entre amigos, o que remete para uma dimensão do consumo associada às sociabilidades.

As consequências podem ser da mais variada ordem: desde a dimensão fisiológica, à dimensão mental e psicológica, passando pela dimensão social. $\mathrm{Na}$ dimensão social, pode afetar áreas como a relação com a família, com o companheiro, com os amigos ou outras pessoas, a performance no trabalho, o desempenho escolar, gestão financeira, entre outros. Pode, em casos de descontrolo, levar à situação de dependência, à marginalização e estigmatização, e ao desenvolvimento de comportamentos delinquentes.

Atualmente, e com a deslocação do problema do consumo da área da justiça para a área da saúde, estes consumos deixam de ser considerados apenas como infração, para passarem a ser tidos enquanto questão de saúde privada e saúde pública. Trabalha-se, portanto, na sua prevenção, no seu tratamento e nos acompanhamentos sociais adequados a estes comportamentos de consumo, e em particular aos comportamentos aditivos e dependências. Por essa razão, nos últimos anos alargou-se o domínio de reflexão sobre os consumos para além das substâncias físicas, e o centro passou a ser as práticas e comportamentos, incluindo aqueles que decorrem de novas formas de vida na sua relação com as novas tecnologias: a adição ao jogo (sobretudo online) e à internet.

\section{Drug Use}

Psycho-active substances, usually also referred to as drugs, are products that, when taken in or administered into one's system, potentiate a physiological effect and cause behavioural changes. Drugs can be classified in 
different ways; the most common classification is the one differentiating substances as stimulants, depressants, narcotics and hallucinogens. They also differ in their legal character (licit and illicit), depending on the normative framework of each society. According to the latest general population survey on drug use in Portugal, the most commonly used substances are cannabis, cocaine and ecstasy (Balsa et al., 2018). Studies on drug use also focus on the prevalence of alcohol, tobacco and sedatives or stimulants without a prescription.

The use of drugs is one of the risk behaviours in society in general and affects youngsters in particular. Young people can show signs of definite insecurity regarding new lifestyles: responsibilities gradually increase towards a greater autonomy and emancipation; social contacts, social roles and routines change, and diversify and intensify in some cases. Related to these changes, there are expectations to be managed - from themselves and from others, facing internal (desires, aspirations and overall development of young adults) and external (society and the labour market) demands. It is also a stage of personal affirmation and of needing to belong to a group. The influence of peers, the desire to anticipate and replicate adult behaviours, the curiosity and the challenge of experimenting, and the temptation to test normative limits, are some of the reasons that lead to a first experience of drug use and that may foster the development of a more regular, more intense and even more problematic use, leading to situations of addiction with severe physical, mental and social consequences.

Thus, young people tend to adopt unhealthy behaviours, many of which are associated with drug use. According to the most recent European results in national youth surveys (EMCDDA, 2016), two out of ten young people smoke regularly, seven out of ten drank alcohol in the last year and two to three of them had binge drinking (when girls consume over four drinks or boys over six over a short period of time), and one or two out of ten have tried any kind of drug (the most common is cannabis). Both in the general population and among youngsters, the prevalence varies by gender and the use is more frequent among boys. However, recently there has been a progressive increase in drug use prevalence among girls compared to the use patterns among boys, especially the use of tobacco, alcohol and cannabis.

The most frequent contexts for drug use are the parties related to rites of passage (New Year's Eve, the end of the school year, graduation) and organized recreational and cultural events (rave parties, trance, summer festivals). 
The use of drugs with friends is frequent, which points to a dimension associated with sociability.

The consequences can be varied: from the physiological dimension to the mental, psychological and social ones. In the social dimension, it can affect areas such as the relationship with family, partner, friends or others, work performance, school performance, and financial management, among others. In cases of lack of control, it can lead to addiction, marginalization and stigmatization, and the development of delinquent behaviours.

Nowadays, and with the shift of the problem from the justice area to the health area, drug use is no longer considered only as an infraction, but also as a matter of private and public health. Therefore, prevention, treatment and social support are appropriate for these consuming behaviours, and in particular for addictive behaviours and addictions. For this reason, in recent years, investigations into consuming behaviours have been broadened beyond the physical substances, and the focus is now on practices and behaviours, including those emerging from new lifestyles with new technologies, associated with gaming and gambling (especially online) and with the internet.

\section{Referências / References}

Balsa, C., Vital, C. \& Urbano, C. (2018). IV Inquérito Nacional ao Consumo de Substâncias Psicoativas na População Geral, Portugal 2016/17. [Gerenal Population Survey on Drugs Use and Abuse Portugal 2016/17] Lisboa: SICAD. ISBN 978-989-99574-9-7. Acceded at: http://www.sicad. pt/BK/Estatisticalnvestigacao/EstudosConcluidos/Lists/SICAD_ESTUDOS/Attachments/181/ IV\%20INPG\%202016_17_PT.PDF)

EMCDDA (2016). ESPAD Report 2015 - Results from the European School Survey Project on Alcohol and Other Drugs. EMCDDA, ESPAD: Lisboa. ISBN: 978-92-9168-919-4. Acceded at: http://www. emcdda.europa.eu/system/files/publications/3074/ESPAD_report_2015.pdf

SICAD. Definiton of Illicit Substances. Acceded at: http://www.sicad.pt/PT/Cidadao/ SubstanciasPsicoativas/Paginas/default.aspx 